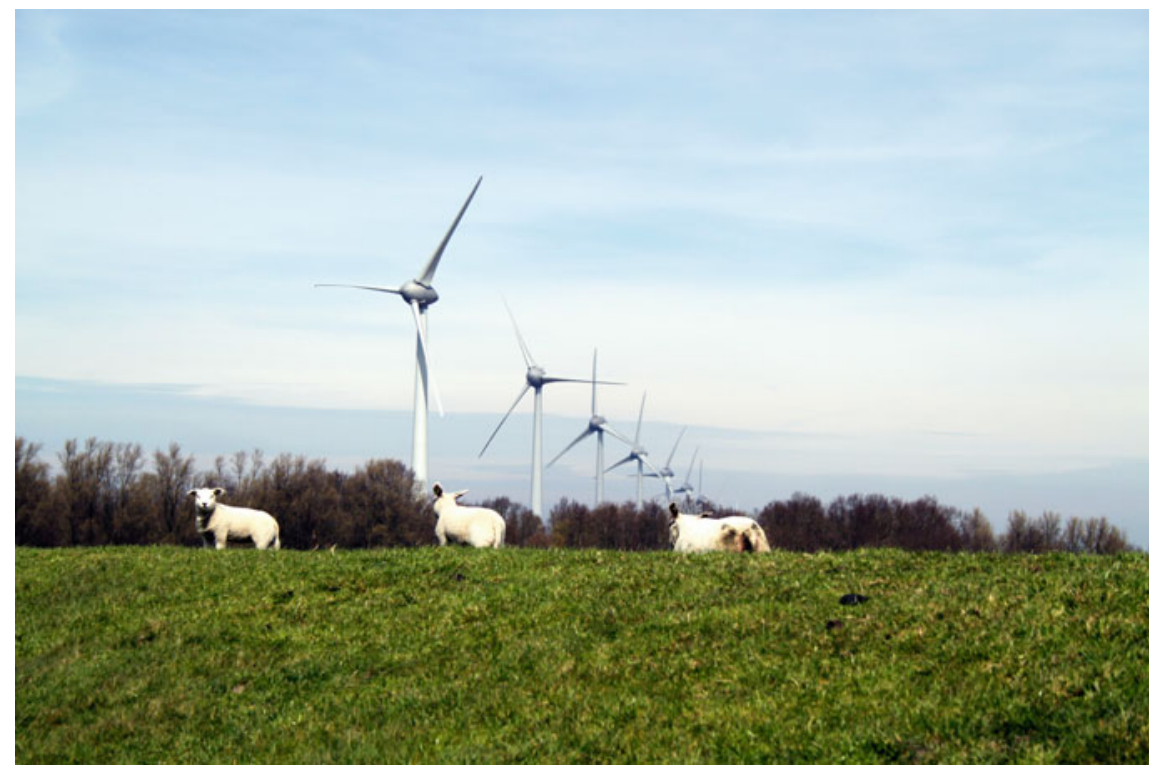

The windmill park in the Noordoostpolder at Westermeerdijk 2015, Wikimedia, released under a Creative Commons Attribution-Share Alike 4.0 International license 


\title{
Chapter 11 \\ The Noordoostpolder: A Landscape \\ Planning Perspective on the Preservation and Development of Twentieth-Century Polder Landscapes in the Netherlands
}

\section{Steffen Nijhuis}

\begin{abstract}
The Netherlands has a centuries-long tradition of reclaiming land. In the last century gaining land from water peaked with the IJsselmeerpolders, made possible by technical innovations. The Noordoostpolder (1937-1942), one of the IJsselmeerpolders, is a unique example of a fully designed agricultural landscape of the twentieth century. It is the first Dutch modern polder in which the layout was planned as an integral task, involving all its agricultural, urban, and landscape elements at once, while reflecting the state of the art in design, science, and engineering. Using the Noordoostpolder as an example, this chapter discusses the preservation and development of twentieth-century polders as cultural heritage landscapes. It elaborates a preservation-through-planning approach that takes spatial development with historical landscape structures as a basis. The chapter also briefly elaborates a critical way of understanding the coherence and variation of modern landscapes such as the Noordoostpolder, providing clues for spatial planning by systematically delineating and identifying spatial design principles.
\end{abstract}

Keywords Land reclamation · Protection through planning $\cdot$ Landscape planning $\cdot$ Industrial agricultural landscape $\cdot$ Noordoostpolder $\cdot$ Heritage landscape

\section{Introduction}

Polders are a significant type of water landscape that humans have created in coastal and alluvial lowlands all over the world by reclaiming land from water. Here, water levels are artificially controlled for food production and everyday life. Interaction between humans and water has produced a rich variety of polder landscapes throughout the ages, in the Netherlands ranging from the tenth to the twenty-first century (Nijhuis 2016; Van der Ven 2004). Globally, polder landscapes are under threat due

\footnotetext{
S. Nijhuis $(\varangle)$

Delft University of Technology, Delft, The Netherlands

e-mail: S.Nijhuis@tudelft.nl

(C) The Author(s) 2020

C. Hein (ed.), Adaptive Strategies for Water Heritage,

https://doi.org/10.1007/978-3-030-00268-8_11
} 
to climate and economic change: increasing flood risk due to sea-level rise, ongoing subsidence due to intense drainage, and rapid urbanization. These valuable cultural heritage landscapes must be safeguarded; knowledge development can provide clues for preserving and transforming them in ways which acknowledge and cultivate their local variation and regional coherence. Polder landscapes are not only important hydraulic phenomena but also spatial constructions and cultural expressions: The polder landscape as one can see and experience it is also a display of tacit knowledge - the kind of knowledge that is difficult to transfer to another person by means of writing it down or verbalizing it — and symbolic values related to land reclamation, water infrastructure, agricultural practice, and landscape planning and design.

This chapter presents a landscape planning approach for protecting and developing twentieth-century polders as cultural heritage landscapes. ${ }^{1}$ Landscape planning is concerned with the long-term development and preservation of natural and cultural landscapes, developing and implementing strategic goal-oriented concepts, and allocation of types of land use. It also addresses design aspects such as form and meaning, develops design principles, and seeks to organize a variety of structural landscape elements in a physical, functional, and aesthetic arrangement. Specifically, this chapter introduces an approach that can be characterized as 'preservation through planning,' which takes landscape development with historical landscape structures as a basis. The chapter will also elaborate a critical way of understanding the coherence and variation of these landscapes, providing clues to developers and planners for spatial planning and design by systematically delineating and identifying spatial design principles. The Noordoostpolder, a unique and completely designed polder landscape from the twentieth century in the Netherlands, serves as an example (Figs. 1 and 2).

The next section introduces the Noordoostpolder as the twentieth-century cultural heritage landscape. Then, the chapter elaborates on the protection-through-planning approach to the countryside in the Netherlands, and how this approach is implemented in the region. The section before the conclusion will briefly introduce an analytical framework to identify landscape design principles that can successfully facilitate new development and guide landscape change.

\section{The Noordoostpolder as a Twentieth-Century Cultural Heritage Landscape}

Reclaiming land is a centuries-old tradition in the Netherlands. In the last century it peaked in size with the IJsselmeerpolders, made possible by technical innovations. In the centuries before, land reclamation had often been a strategy by which landowners extended their holdings, an investment by rich merchants, or was a public undertaking. In the case of the IJsselmeerpolders, the Dutch government wanted to

\footnotetext{
${ }^{1}$ This paper is based on an invited lecture presented at the 'International symposium on conservation and utilization of modern industrial heritage; contemporary subjects in the Netherlands, Italy, China, Germany, Indonesia, and Japan.' Tokyo, March 4, 2017, and March 5, 2017.
} 


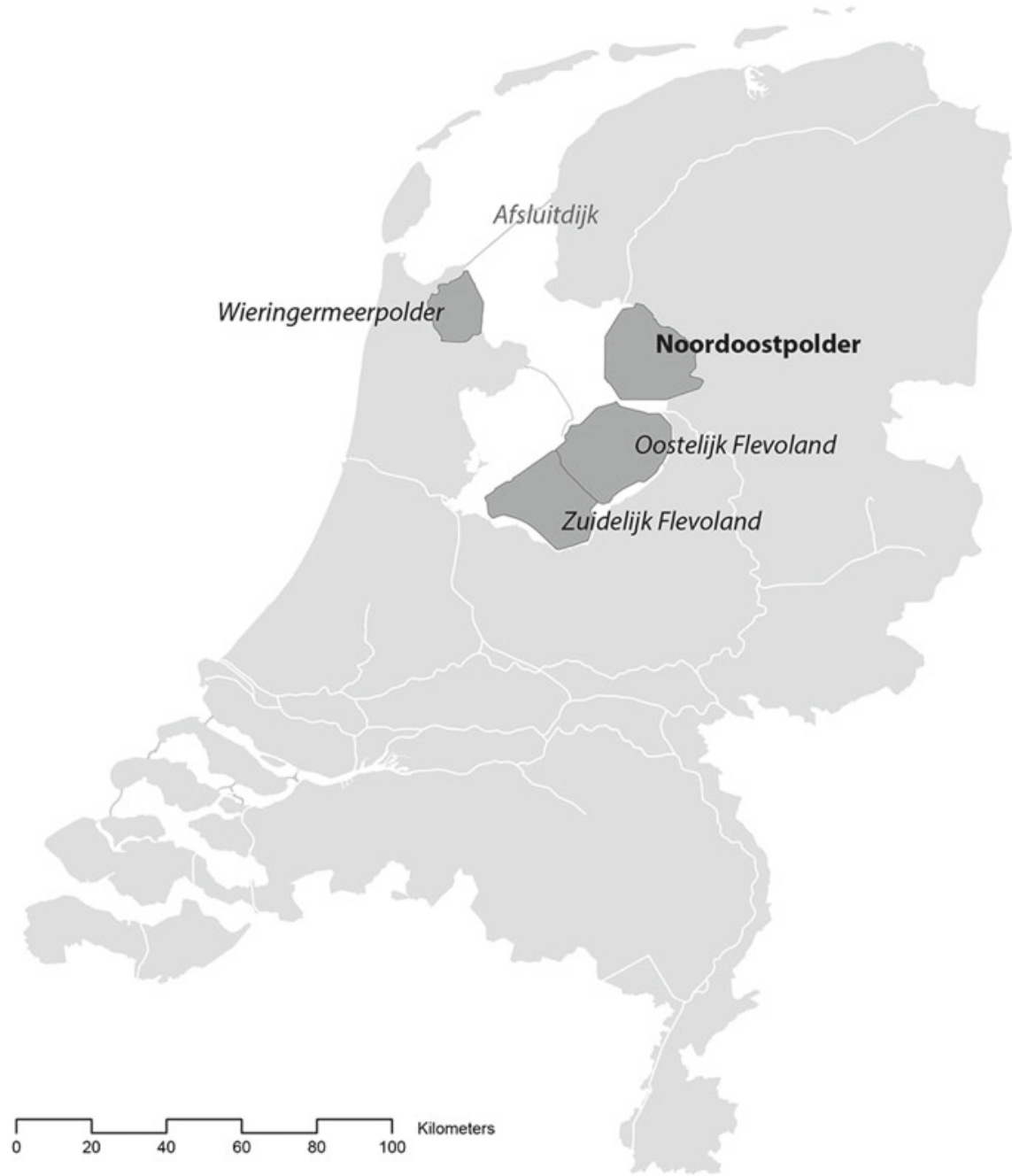

Fig. 1 The IJsselmeerpolders in the centre of the Netherlands (S. Nijhuis, Delft University of Technology)

safeguard food provision for the nation by providing agricultural land; later, urban development became an important motive. The IJsselmeerpolders-Wieringermeerpolder (constructed 1927-1930), Noordoostpolder (1937-1942), Oostelijk Flevoland (1950-1957), and Zuidelijk Flevoland (1959-1968) — provide almost ten percent of the total arable land in the country today $(1,045,000 \mathrm{ha})$.

In general, there are three important types of land reclamation: (1) impoldered low-lying lands, (2) drained lakes, and (3) lands reclaimed from the sea. During the construction of these polders, open water or waterly lowland is turned into landscapes 


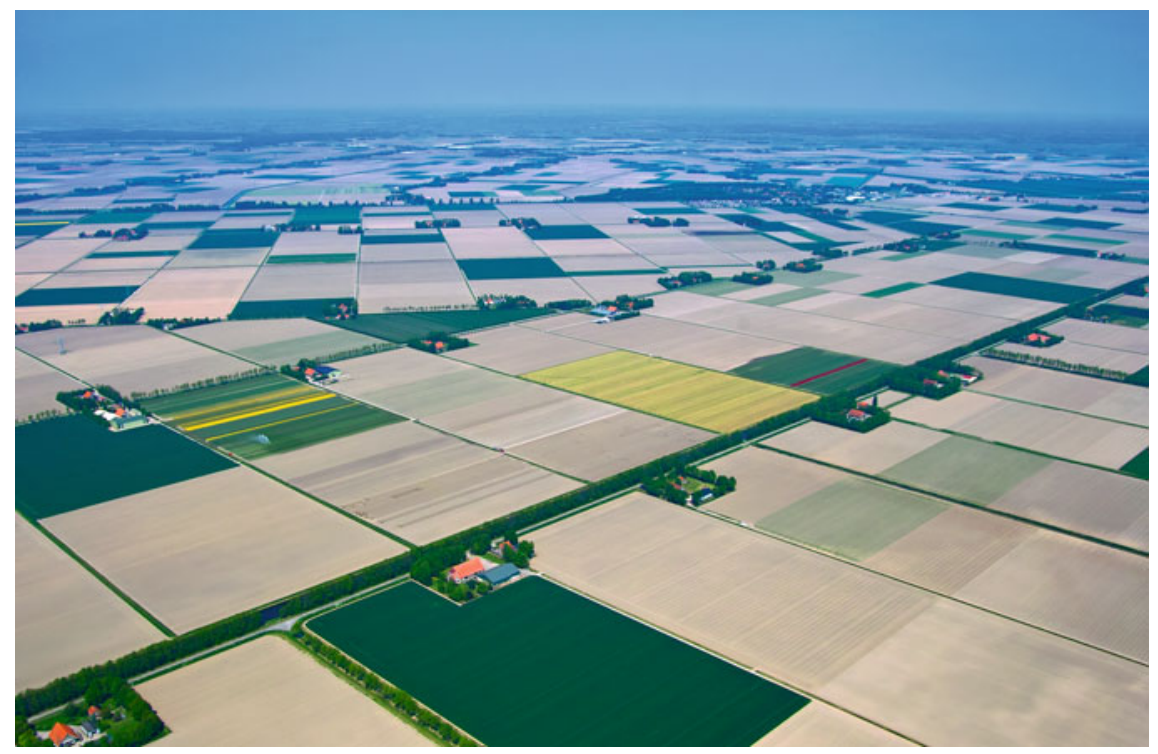

Fig. 2 The Noordoostpolder (Paul Paris)

for working and living and therefore includes flood protection, drainage, and often irrigation. Modern polder landscapes as such are not only part of the history of hydraulic engineering and industrial agriculture, but also territorial expressions of the interaction of physical conditions, knowledge, and management in the Dutch cultural and political context of the twentieth century (Fig. 3). The IJsselmeerpolders, lands reclaimed from the sea, are truly cultural landscapes that are defined and shaped by cultural perceptions and practices and, in turn, shape and structure social and cultural experiences (cf. Head 2000). Considering polders as cultural landscapes broadens concepts and understandings of cultural heritage past monuments and sites and exemplifies the interdependence of social, aesthetic, ecological, and economic functional values, and puts polder landscapes forward as an important subject for water and heritage studies.

The Noordoostpolder (NOP) was the first IJsselmeerpolder, drained after the completion of the Afsluitdijk in 1932. The dikes for the polder were built between 1937 and 1941, and the polder was dry in 1942 (RIJP 1986-1990). The two former islands of Schokland and Urk were also included in the polder. The polder has an area of $48,000 \mathrm{ha}$; it measures $26 \mathrm{~km}$ from north to south and $24 \mathrm{~km}$ from east to west. The NOP is a unique example of a fully designed landscape of the twentieth century, really a 'Gesamtkunstwerk,' or a total piece of art with a coherent perspective on architecture, urban planning, landscape architecture, civil engineering, and land-use planning (Fig. 4). It is the first modern Dutch polder in which the layout was planned as an integral task, involving all its agricultural, urban, and landscape elements at once (Minderhout et al. 1955). In general, much had been learned from the drain- 


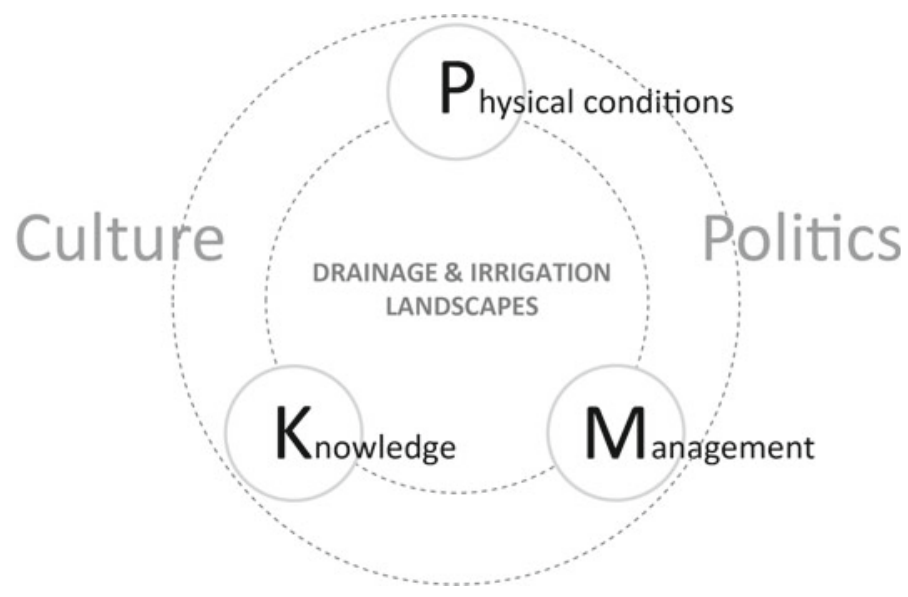

Fig. 3 Polder landscape as territorial expression of the interaction of physical conditions, knowledge and management in the Dutch cultural and political context (S. Nijhuis, Delft University of Technology)

ing of the Wieringermeer. But if one considers the Wieringermeerpolder to be the prototype of modern, twentieth-century land reclamation, then the NOP is the first mature example in the Netherlands. It would in turn become an exemplar for other modern land reclamations, including the Hachirogata Polder (1963-1966) in Japan (HIPO 1969).

The NOP was designed for optimal agricultural production and was also regarded as a scientific, aesthetic, and intellectual project. For the aesthetic aspects of the polder, the publication 'The future landscape of the Zuiderzee polders' (1928) was a great influence (Fig. 5). This manifesto is today regarded as an important milestone in Dutch urban and landscape planning. Here, influential Dutch modernist planning experts such as Dirk Hudig and Theodoor van Lohuizen put forward preferred principles for landscape design, derived from comparing the Beemster, the seventeenth-century polder, to the Haarlemmermeer, a polder from the nineteenth century. They regarded the first as a successful example, and the latter a less successful one. Sociologists and agricultural engineers also helped set up the NOP, paying attention to questions of future population, the role of transport, and the location of population cores. The various scientific movements and professional disciplines came into conflict with one another in the discussion on the ideal design of the NOP (Geurts 1997; Bosma and Andela 1983), so negotiation, planning, and realization played a more important role than ever before.

Landscape planning began to play an increasingly important role in spatial design, as a counterpart to the urban planning of the polder addressing landscape as an important element in planning. Specifically, a landscape framework-based on soil, geography, and landscape history_made space for nature and recreation, enriching 


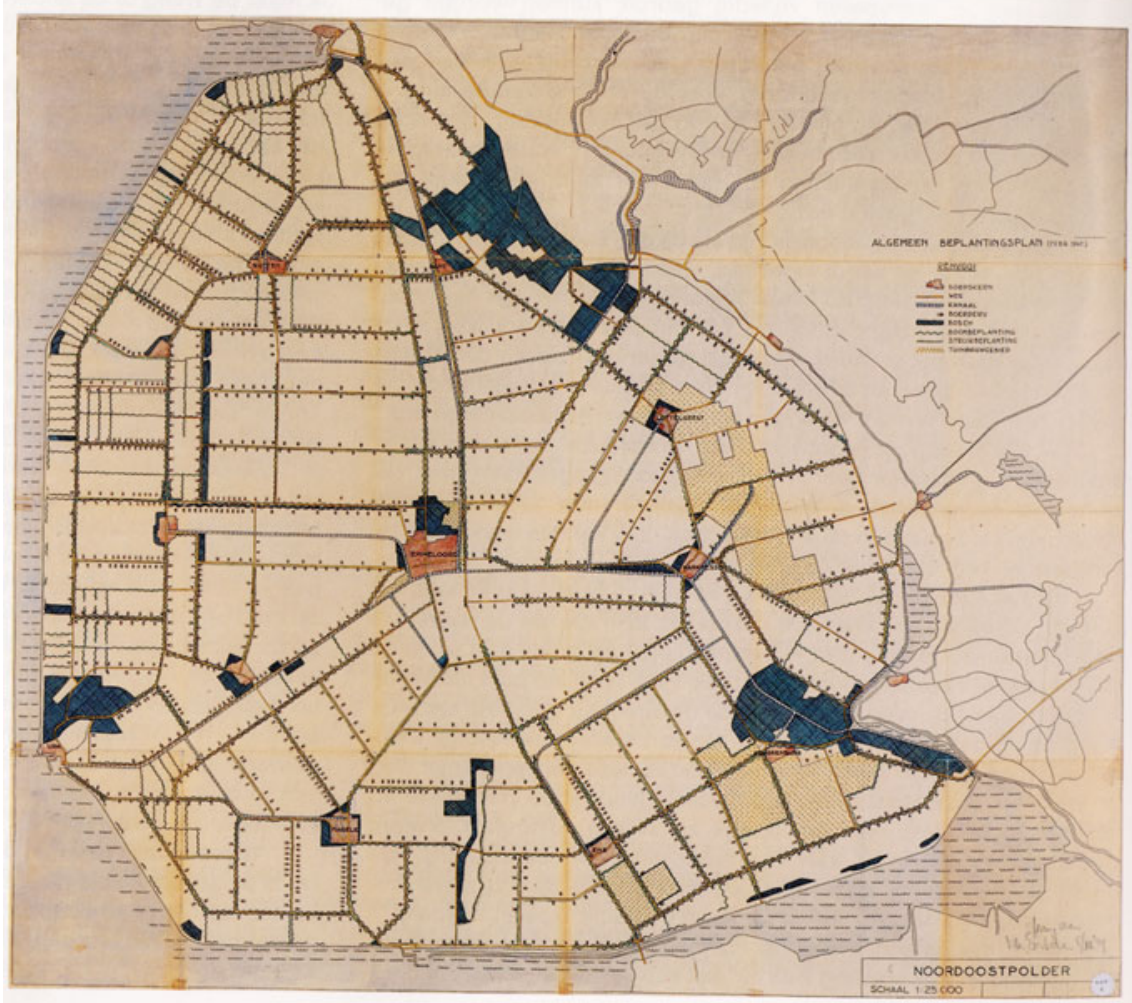

Fig. 4 General planting scheme of the Noordoostpolder, 1947 (Nieuw Land)

the network of roads and villages that urban planners laid over the polder land (as in the Wieringermeer).

Centrality plays a major role at every level in this polder. Emmeloord, with the polder tower (Netherland's highest water tower) as its center, is the center of concentric rings: the ring of villages, a condensed outer ring, and the dike ring. The landscape planners conceived woods and grassland in 'polder rooms' for the edges of the polder; the heart of the polder has a high degree of landscape openness and is used for arable farming. The allocation of the land and the concentric structure of the road system and village pattern all support this articulation of the polder space into 'rings.' At a smaller scale, one finds the concentric structure in the spatial plan of the villages, and in the farmsteads, grouped around the intersection of a polder road and drainage ditch, at the corners of the parcels.

The ten villages in the polder are planned at regular intervals and circle around Emmeloord, the capital of the polder. Architects or consultants employed by the government designed most of the villages in the NOP, laying each out according to the principles of the Delft School, with tradition as the guide. The hierarchical spatial 


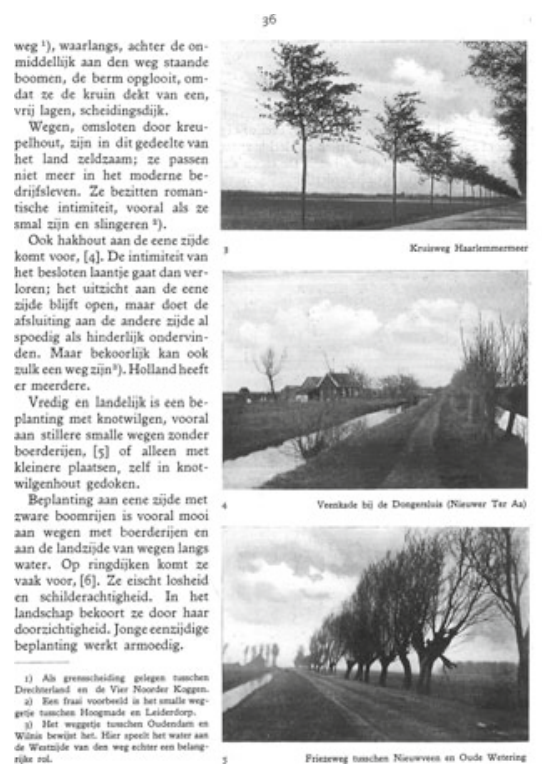

37

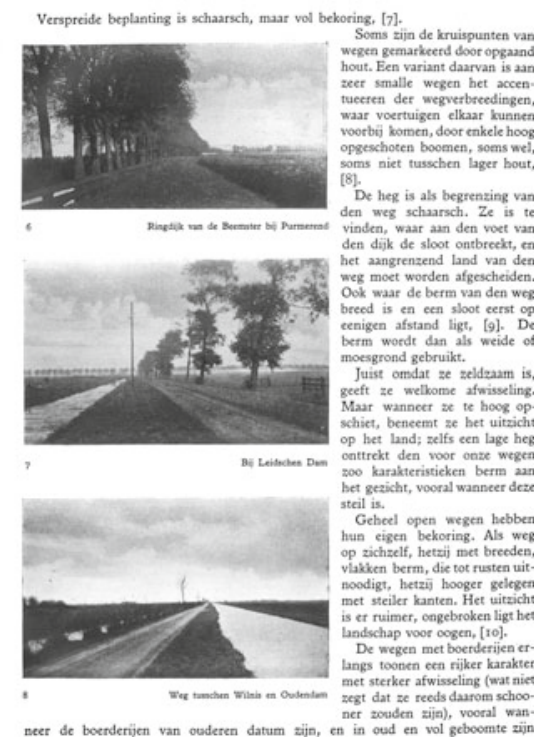

Fig. 5 Pages from 'The future landscape of the Zuiderzee polders', 1928

form of the villages, turned in on itself, was intended to serve as a counterpoise to the dislocations of urbanization and industrialization. In elaborating the plans, the designers experimented with architectonic concepts in the spirit of Camillo Sitte that were based on aesthetically pleasing historical examples.

The village of Nagele was an exception. Here, influential Dutch urban planners and architects such as Cornelis van Eesteren, Gerrit Rietveld, and Aldo van Eyck, among others from the Modernist collectives 'De 8' en 'Opbouw', came up with their own initiative to design the village and apply their planning ideas (Van Woensel 1999; Van der Wal et al. 1992; De 8 en Opbouw 1952). They structured Nagele systematically and evenly, and they separated the major urban functions-living, working, traffic, and recreation. The central open green space, surrounded by urban facilities and seven neighborhoods, illustrates a new organization of society. The design and construction of Nagele also formed the first turn to the urbanization of the countryside (Fig. 6).

As such the NOP reflects the state of the art in landscape and urban planning, architecture, agricultural and social science, and engineering in the second half of the twentieth century, at multiple spatial scales, from the region to the building. Therefore, the NOP can be regarded as a cultural heritage landscape. 


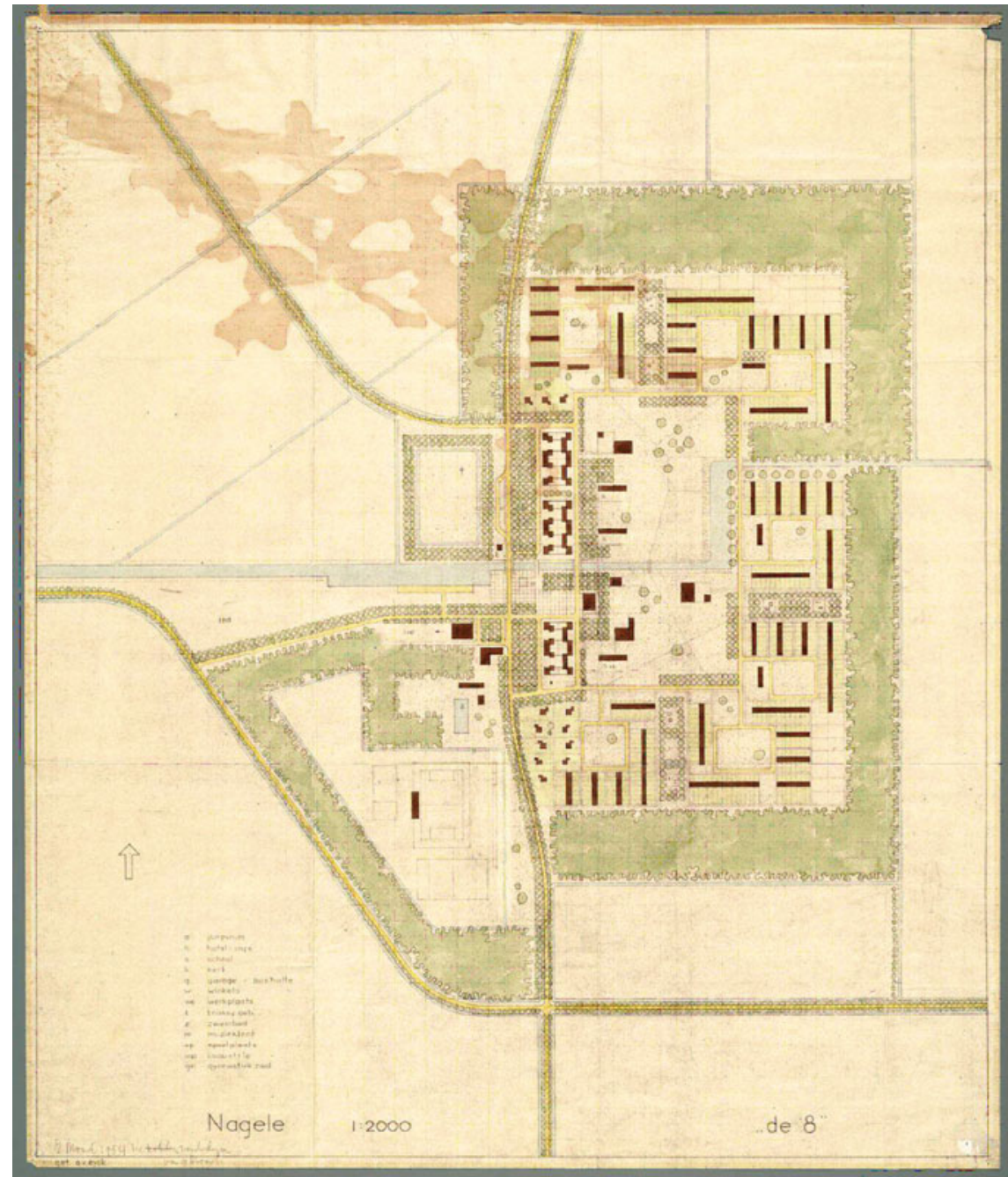

Fig. 6 Nagele, final design by Aldo Van Eyck, 1954 (NAi)

\section{Protecting Polder Landscapes Through Planning}

A cultural landscape is defined as an area, as perceived by people, whose character is the result of the action and interaction of natural and/or human factors (Council of Europe 2000). This definition stresses the dynamic character of landscapes. Polders change, as does every landscape with and without human interaction. Sometimes there are profound changes taking place, sometimes less radical changes. A landscape is a dynamic system that is continually transforming under the influence of natural 
processes and social requirements. Linking the past to the present, the landscape is a layered entity, a palimpsest where traces that time has covered can reinforce or contradict each other; it is a window into a range of histories, chronologies, events, and meanings connecting the traditional and the contemporary, the tangible and the intangible.

Managing and preserving heritage landscapes are very different from protecting a site or monument. The landscape is always open to significant change on a variety of timescales even without human intervention. Its perceptual aspects are just as dynamic as its physical ones: People change their view of the world and thus their landscape for several reasons. In other words, a cultural landscape cannot be preserved unchanged (Fairclough et al. 2008). Preservation of cultural landscapes should focus on the 'management of change,' aiming to create a future in which the past in one form or another plays an appropriate role (Fairchlough et al. 2008).

The landscape of the IJsselmeerpolders is subject to distinctive kinds of change. The NOP is now 75 years old, and most of its layout and buildings are still in place and recognizable. However, it is also a living landscape, where people live, work, and spend their leisure time. Protecting and developing this cultural landscape requires careful attention to this combination. Moreover, rapid urban development, function change, and climate change can level or standardize these rural landscapes, negating their characteristic spatial differences and risking the loss of cultural identity.

The legal instruments (such as the Dutch Monuments and Historic Buildings Act 1988/2012) that aim to preserve the state of monuments and sites do not apply to such living cultural landscapes that continuously change due to agrarian and other economic developments. In the Netherlands, where agricultural systems are the most intensive in Europe, the legal protection of cultural heritage landscapes is extremely problematic. In fact, the Netherlands is one of the few countries with hardly any protected cultural landscapes (UNEP-WCMC 2017). The Dutch government did recently ratify the European Landscape Convention (Council of Europe 2000), which promotes the protection, management, and planning of European landscapes and organizes European cooperation on landscape issues; this illustrates that cultural landscapes are high on the political agenda. And three cultural landscapes were designated as world heritage in recent decades: Schokland and Surroundings (1995), the Defense Line of Amsterdam (1996) and the Beemster Polder (1999) (World Heritage List 2017). However, these are weak forms of protection, since they have hardly any legal basis. More largely, political pressure from landowners, in particular farmers and their representatives, makes it almost impossible to protect landscape with legislation because it leaves little space for future development.

But that does not mean that cultural landscapes have no protection in the Netherlands. During the second half of the twentieth century, the protection of cultural landscapes became part of the political discussion that resulted in important spatial planning instruments embedded in the Dutch Spatial Planning Act. An important milestone in this respect was the 1977 policy document, Vision on Landscape Construction, that pleaded for the integral development of the landscape using its existing structure and its historical situation as a basis in order to ensure that development created a recognizable environment with its own identity. This was followed by the 
first national mapping of cultural values in the rural area by the national government (CRM 1979).

Another important document was the 1999 Belvedere Memorandum, a national policy document that examined the relationship between landscape history and spatial planning. It considered cultural historic values important to identity and a sense of purpose, a resource against globalization, a source of information and inspiration, and forms of aesthetic, ecological, and economic importance. Conservation through development is its motto. By seeking new uses for historical landscapes and buildings, cities and countries can save them; by using cultural heritage in a frugal and responsible manner, one could invest in developing and strengthening of identity, knowledge, comfort, the business climate, and the potential for tourism (Belvedere 1999). The document proposes that the interaction between cultural history and spatial planning, and the recognition of the difference in perspectives of stakeholders, can create the conditions for discovering a new balance between retaining cultural heritage and developing it (Belvedere 1999). This process of development can help renew citizens' engagement with cultural heritage.

This type of policy document influenced Dutch planning, inviting professional groups, already directed toward the future, to look backward, and encouraging historians, who used to look only backward, to take stock of the future (Bosma 2010). The result was planning instruments that embraced the idea that historic valuable landscapes should be used in such way that preserves them and at the same time gives them a valuable use. But how are these principles put into practice?

\section{Planning Instruments and the Noordoostpolder}

Statutory spatial plans play an important role in land-use planning and management in the Netherlands. The Dutch Spatial Planning Act prescribes and regulates statutory spatial plans attending to cultural heritage (and other issues) at the level of the national government, the province, and the municipality (Needham 2007).

The Dutch government can set spatial policy in different ways, but works mainly through national structure plans for a policy sector or broad aspect of spatial policy, and through a Memorandum on Spatial Planning. In 2012, the National Policy Strategy for Infrastructure and Spatial Planning came into force. In this policy document, the NOP as a whole is among the thirty selected areas that jointly exhibit the social dynamics of the reconstruction of the Netherlands after World War II (in the period 1940-1965). The complementary National Policy Strategy for Heritage and Space explains the core qualities of these areas, describing the NOP as large-scale land reclamation with rationally distributed agricultural farmhouses and yards and a functional pattern of roads with associated planting. It also notes the ring of villages around the main core (Emmeloord) as an important characteristic. According to this plan, provinces and municipalities should model new development on these characteristics in their future planning. 
Here, the Dutch government focuses on administrative agreements with provinces and municipalities on development-oriented protection zoning. It asks a province to make a Provincial Regional Plan or a Provincial Environmental Plan setting out the desired future development of the province. That plan is self-binding: It binds the province to act in accordance with its own plan and coordinates the actions of the province itself. Because the province is empowered to regulate the action of lower authorities, it can have great consequences for the involved municipalities: It can give or withhold approval to their new Municipal Zoning Plans. For the NOP as a whole, the Environmental Plan Flevoland 2006-2015 is still in effect, offering a policy framework for the municipalities to elaborate on. It puts forward ambitions for enhancing the vitality of the landscape (e.g., new functions), ensuring and improving the quality of the countryside (e.g., strengthening spatial structures), and handling existing situations and functions (e.g., facilitating development). The plan cites the World Heritage site, Schokland, and the villages Urk and Nagele as important basic features of the NOP that needs to be preserved, some historical objects (e.g., pumping stations, bridges), the main water courses, the inner ring road, and the open landscape in the center.

On the municipal level, the Municipal Structure Plan (which is not obligatory) sets out the desired future development of the municipality as a whole, including the framework for the zoning plan(s) and the plans for various sectors of the municipality (e.g., housing, transport, employment). The most important planning instrument is the Municipal Zoning Plan, which sets out the activities which may make take place on the land in a designated area, 'in so far as this necessary for good ordering of land.' This zoning plan is the basis on which a municipality can grant permits for development. It is the only operational plan. The zoning plan can be very general or very detailed and is legally binding. Municipalities are also obliged to make a land-use plan for the land outside the built-up areas, which is to say the rural areas. The 'Rural Zoning Plan Noordoostpolder 2004' is the most important plan for the landscape of the NOP. It is a generic planning framework for the protection and development of this rural area, focused on regulating the main land uses.

The municipality is by law obliged to update zoning plans within ten years. At present, environmental issues in relation to agriculture make it practically impossible for the municipality to update the zoning plan for the NOP. As a step in the process for meeting the requirement, the municipality chose therefore to establish a Management Regulation for the Countryside 2016. The plan specifically mentions several important historical features that developers should take into consideration: the parcellation structure (form, size, and proportion of the plots themselves and their constellations), the farms and yards, and three types of farmhouses. The recently published structural vision Noordoostpolder 2025 provides the basis for the new Municipal Zoning Plan (whenever it can be updated) and is strategic in nature. The structural vision is primarily intended to seduce and inspire stakeholders and to promote initiatives and investments that will contribute to responsible development of the countryside. It also reiterates the enforcement of its cultural-historical and landscape values through descriptions and maps (Fig. 7). 


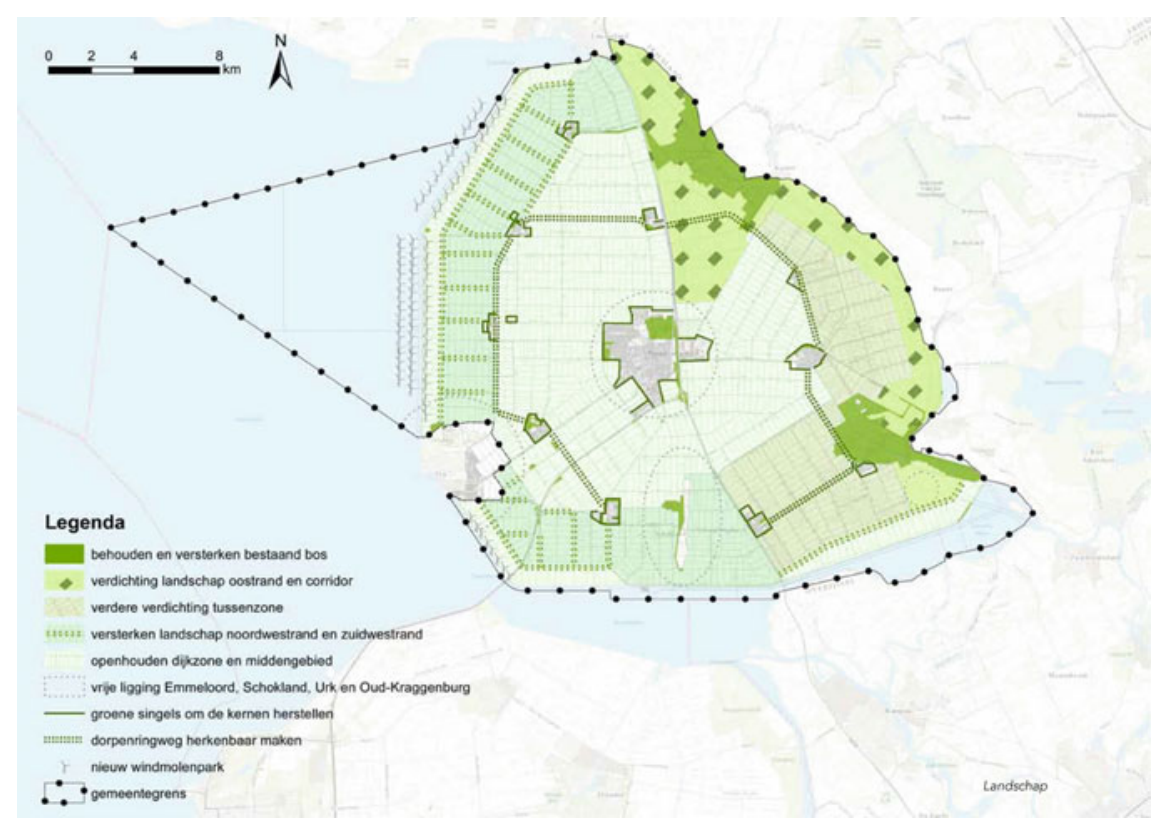

Fig. 7 Landscape value map from the recent Structural vision Noordoostpolder 2025 (Municipality Noordoostpolder, Kuiper Compagnons)

In the Netherlands, such statutory plans protect landscapes such as the NOP to some degree by indicating the landscape character and describing historical landscape structures. However, the plans remain descriptive, only identifying important characteristics in a very general way and providing hardly any clues for how developers or municipalities might make use of them in future plans. Though often perceived as restrictive, the plans do leave room for developers to interpret them-which often results in 'misinterpretations' and destruction of important landscape features, such as the characteristic structures and openness of polders (e.g., encroachment of typical open areas by new farm buildings).

\section{A Critical Design Perspective for Development and Protection}

In the NOP, development means adapting the polder to agricultural demands (e.g., extra and bigger farm buildings), to housing projects, and to energy transition away from fossil fuels (e.g., wind turbines, water storage). In order to accommodate such development within a cultural heritage landscape, and to facilitate change in an effective way, a design perspective is needed. Design is about changing situations into preferred ones and is future-oriented. Therefore, describing and indicating the 


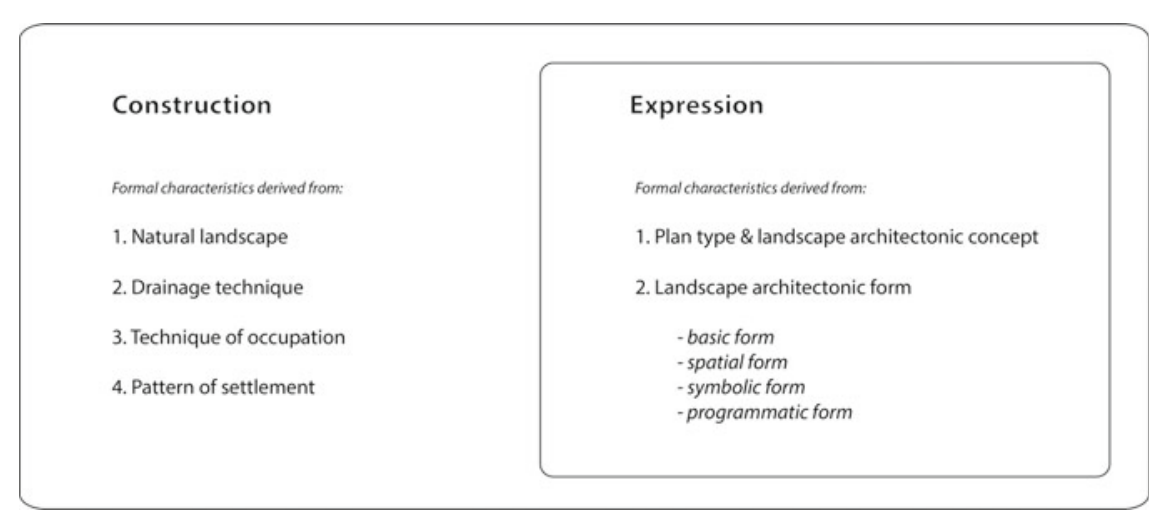

Fig. 8 Analytical framework for the identification of the polder grammar (S. Nijhuis, Delft University of Technology)

landscape character, as the statutory plans do, is not sufficient. Planning instruments should also provide design knowledge to guide and direct landscape change in a responsible manner, while providing clues for spatial development in the form of design principles or - in this case 'polder grammar.' The polder grammar is the set of structural rules and principles that determines the characteristic composition of the landscape: the complexity of the pattern, the morphology, the visual qualities-and with that, the cultural identity of the polder. Knowledge of the polder grammar is the starting point for new changes in the landscape or adding a new design layer. It respectfully guides and directs landscape change.

We have developed an analytical framework to identify and delineate polder grammar systematically (Nijhuis 2016; Steenbergen et al. 2009). It employs historical maps, newly drawn maps, and photographs to identify the constructive characteristics and the expressive characteristics of the polder form. The constructive characteristics are the formal aspects of the historical transformation of the natural landscape into a habitable and exploitable agricultural landscape. The expressive characteristics are the implicit and explicit visual and formal elements, the compositional, aesthetic, and cultural motifs of polder making (Fig. 8). We understand the polder landscape to be a layered entity, defined first by the underlying natural landscape, to a further degree by hydraulic interventions, and finally by the organization imposed by the agricultural development of the land (Fig. 9). Each stage leaves its traces on the form of the polder. Identifying and delineating this complex layering creates a point of contact between the landscape and developers or municipalities dealing with technical and landscape planning questions, such as water management or urbanization, and thus provides clues for their further development of the polder landscape.

Through design experiments based on the polder grammar, on multiple scale levels, one can investigate which elements from the polder landscapes can be changed to adapt them to economic and climate change without damaging the overall integrity of the polder and how to change them. Research by design, exploring possibilities 


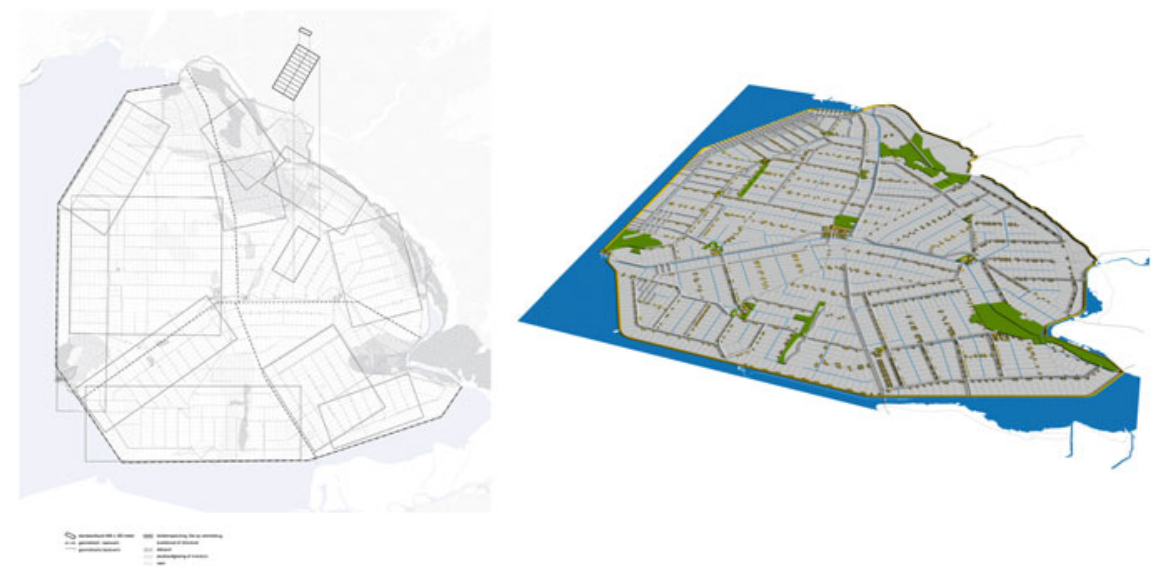

Fig. 9 Some applications of the analytical framework to the Noordoostpolder on the regional scale (S. Nijhuis, Delft University of Technology)

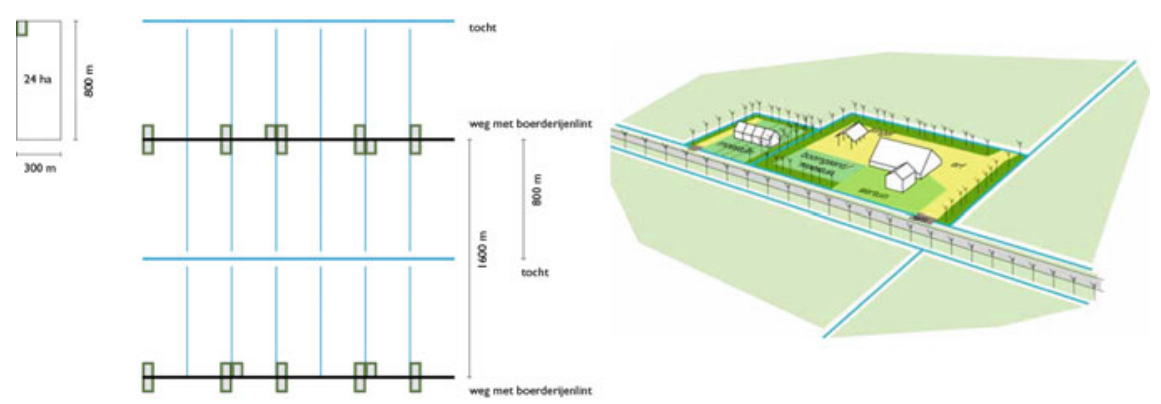

Fig. 10 Typical organization of farms and parcellation in the Noordoostpolder (Feddes 2012)

by spatial design, can help developers, and planners explore the possibilities for spatial development, generating proposals or potential solutions for design problems (Nijhuis and Bobbink 2012). This type of knowledge-based design leads to new, balanced, and coherent polder landscapes with their own identity and spatial qualities. For a full elaboration of the framework see Nijhuis (2016), and application on the NOP and identification of design principles see Steenbergen et al. (2009) and Feddes (2012) (Figs. 10 and 11).

\section{Conclusion}

The preservation and development of cultural heritage landscapes like the NOP is a public valuation of tangible (physical) and intangible (social and political) characteristics of the past and asserts a public interest in things traditionally regarded 


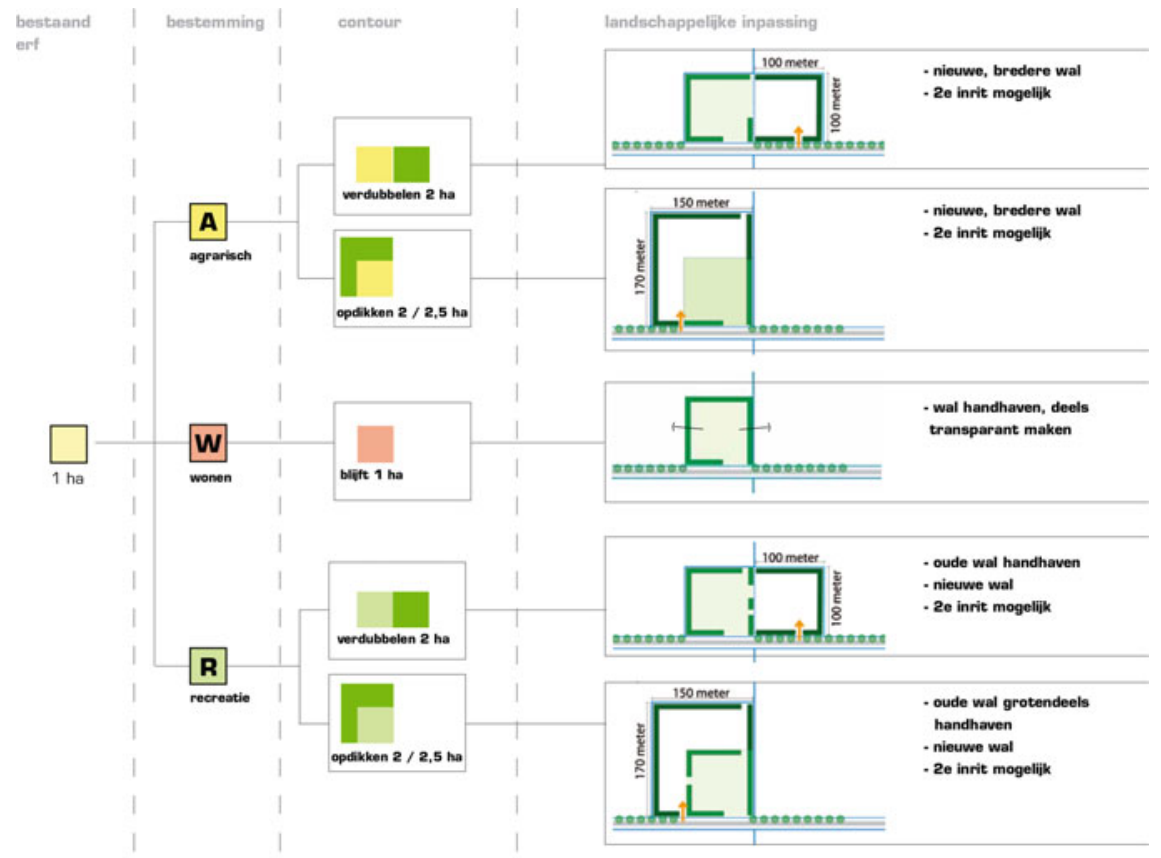

Fig. 11 The development of new farms can be developed based on the design principle (Feddes 2012)

as private. In that respect, heritage landscapes are cultural resources that need to be handled with care. Modern cultural heritage landscapes such the NOP are preserved through governmental planning in the Netherlands, embracing the idea that historic landscape features should be used in such way that preserves them and at the same time gives them a valuable use. This process of protection through planning is more complex and contextual than legal protection. And it is part of a dynamic, political process instead of only belonging to the realm of experts (Renes 2004), which means that more people and organizations are involved. Preservation by planning thus depends on coalitions between partners.

Though the statutory plans in the Netherlands provide an important basis for preservation through planning, with generalized descriptions of important cultural-historical landscape characteristics, the process also calls for augmenting those statutes with design principles in order to make them effective tools for development. Particularly on the provincial and municipal levels, one can find promising developments in this direction, with planners implementing new analytical frameworks for understanding and management as vehicles for translating their ambitions into practical applications. Preservation through planning can build capacity, involve local stakeholders, and stir public debate about the significance of historical landscape features and how to use them in new ways. 


\section{References}

Belvedere (1999) The Belvedere memorandum: a policy document examining the relationship between cultural history and spatial planning. Sdu Uitgevers, The Hague

Bosma K (2010) Heritage policy in spatial planning. In: Bloemers T (ed) The cultural landscape \& heritage paradox: protection and development of the Dutch archaeological-historical landscape and its European dimension. Amsterdam University Press, Amsterdam, pp 641-651

Bosma K, Andela G (1983) The landscape of the IJsselmeer polders. In: Bosma K et al (eds) Het Nieuwe Bouwen, Amsterdam 1920-1960. Delft University Press, Delft, pp 142-174

Council of Europe (2000) European landscape convention. s.n., Florence

CRM (1979) Natuurwaarden en cultuurwaarden in het landelijk gebied: Een inventarisatie. [Natural and cultural values of the countryside: an inventory]. Staatsuitgeverij, Den Haag

De 8 en Opbouw (1952) Een plan voor het dorp Nagele [A plan for the village Nagele]. Forum 7(4/5):172-178

Fairchlough G et al (2008) New heritage, an introductory essay-people, landscape and change. In: Fairclough G (ed) The heritage reader. Routledge, London, pp 297-312

Feddes Y (ed) (2012) Landschapsvisie Noordoostpolder. Landschap van rust en regelmaat. s.n., Utrecht

Geurts A (1997) De Groene IJsselmeerpolders. Inrichting van het landschap in Wieringermeer, Noordoostpolder, Oostelijk en Zuidelijk Flevoland [The green IJsselmeer polders. The design and construction of the landscape in Wieringermeer, Noordoostpolder, Oostelijk en Zuidelijk Flevoland]. Uitgeverij de twaalfde provincie, Lelystad

Head L (2000) Cultural landscapes and environmental change. Arnold, London

HIPO (1969) The record (or history) of the impoldering of the Hachirogata. Hachirogata Impoldering Project Office, Ogata Mura (in Japanese)

Minderhout A, Granpré Molière M, Bijhouwer J et al (1955) De Noord-Oost Polder. Forum 10(1/2): $1-52$

Needham B (2007) Dutch land use planning: planning and managing land use in the Netherlands, the principles and the practice. Sdu Uitgevers, The Hague

Nijhuis S (2016) Polderscapes: the landscape architecture of the Dutch Lowlands. Fengjing Yuanlin (Landsc Archit) 8:38-57. https://doi.org/10.14085/j.fjyl.2016.08.0038.20

Nijhuis S, Bobbink I (2012) Design-related research in landscape architecture. J Des Res 10(4):239-257. https://doi.org/10.1504/jdr.2012.051172

Renes H (2004) Different methods for the protection of cultural landscapes. In: Palang Hannes et al (eds) European rural landscapes: persistence and change in a globalising environment. Kluwer Academic Publishers, Dordrecht, pp 333-344

RIJP (1986-1990) Wording en opbouw van de Noordoostpolder: Geschiedenis van de ontginning en eerste ontwikkeling (1940-ca. 1960) (4 dln.) [Planning and construction of the Noordoostpolder: history of the reclamation and first development] Rijksdienst voor de IJsselmeerpolders, Lelystad

Steenbergen C, Reh W, Nijhuis S, Pouderoijen M (2009) The Polder Atlas of the Netherlands. Pantheon of the Lowlands. THOTH Publishers, Bussum

UNEP-WCMC (2017) Protected area profile for Netherlands from the world database of protected areas. https://www.protectedplanet.net/country/NLD. Accessed 11 Jan 2017

Van der Ven G (2004) Man-made lowlands. History of water management and land reclamation in the Netherlands. International Commission on Irrigation and Drainage, Utrecht

Van der Wal C, Bruggenkamp JWC, Oterdoom D (1992) De ruimtelijke opbouw van de Noordoostpolder. De jongere bouwkunst en stedebouw in de Noordoostpolder in het kader van het Monumenten Inventarisatie Project (MIP) [The spatial construction of the Nooroostpolder]. Ministerie van Verkeer en Waterstaat, Lelystad

Van Woensel J (1999) Nieuwe dorpen op nieuw land. Inrichting van de dorpen in Wieringermeer, Noordoostpolder, Oostelijk en Zuidelijk Flevoland [New villages on new land. The design and construction of villages in Wieringermeer, Noordoostpolder, Oostelijk en Zuidelijk Flevoland]. Uitgeverij de twaalfde provincie, Lelystad 
World Heritage List (2017) Unesco World Heritage List: Dutch properties inscribed on the World Heritage List. http://whc.unesco.org/en/statesparties/nl. Accessed 11 Jan 2017

Dr. Steffen Nijhuis is Head of Landscape Architecture Research, Director European Post-master in Urbanism (EMU), and Associate Professor in the Department of Urbanism, Faculty of Architecture, and the Built Environment, Delft University of Technology. His book publications include: The Polder Atlas of the Netherlands, Delta Urbanism, and Polder Landscapes of the World. He currently works on landscape-based strategies for urban development.

Open Access This chapter is licensed under the terms of the Creative Commons AttributionNonCommercial-NoDerivatives 4.0 International License (http://creativecommons.org/licenses/bync-nd/4.0/), which permits any noncommercial use, sharing, distribution and reproduction in any medium or format, as long as you give appropriate credit to the original author(s) and the source, provide a link to the Creative Commons license and indicate if you modified the licensed material. You do not have permission under this license to share adapted material derived from this chapter or parts of it.

The images or other third party material in this chapter are included in the chapter's Creative Commons license, unless indicated otherwise in a credit line to the material. If material is not included in the chapter's Creative Commons license and your intended use is not permitted by statutory regulation or exceeds the permitted use, you will need to obtain permission directly from the copyright holder.

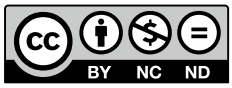

